\title{
INFLUENCE OF BOUNDARY LAYER SCHEMES IN MODELING THE DISPERSION AND SEDIMENTATION OF VOLCANIC ASH IN ECUADOR
}

\author{
RENÉ PARRA \\ Instituto de Simulación Computacional, Colegio de Ciencias e Ingeniería, \\ Universidad San Francisco de Quito, Ecuador
}

\begin{abstract}
Volcanic ash can cause critical air pollution events and other impacts. Atmospheric transport models are pivotal for modeling volcanic ash dispersion. The Planetary Boundary Layer (PBL) - the turbulent atmospheric bottom part which operates on scales that cannot be explicitly represented in models - strongly influences the dispersion of pollutants. We simulated the meteorology over Ecuador, using the Weather Research and Forecasting (WRF3.7.1) model with 7 PBL schemes: (1) Yonsei University (YSU); (2) Mellor-Yamada-Janjic (MYJ); (3) Hong and Pan (GFS); (5) MellorYamada Nakanishi and Niino Level 2.5 (MYNN2.5); (6) Boulac PBL (BL); and (7) Shin-Hong (SH). After, the meteorological outputs were ingested into the FALL3DV7.1.4 model to simulate ash dispersion and sedimentation from 4 eruptions (Tungurahua volcano: 16 Dec. 2012, 14 Jul. 2013 and 1 Feb. 2014) (Cotopaxi volcano: 14 Aug. 2015) which took place in Ecuador in the last 6 years. Modeled ash clouds were qualitative compared with ash clouds detected by the Washington VAAC. Modeled ash fallout quantities were compared with records from ash meters located on stations around these volcanoes. For all the eruptions and all the PBL schemes, the modeled ash clouds were fairly consistent with the detected. The MYJ PBL scheme provided the best performance (R2 $\geq 0.5$ for all the eruptions) in modeling ash fallout quantities. In other assessments, MYJ is among the PBL schemes that provided better performances when modeling the dispersion of air pollutants. These results suggest the MYJ PBL scheme could be a good choice both for volcanic ash and air quality modeling in the Andean region of Ecuador.
\end{abstract}

Keywords: PBL, local scheme, nonlocal scheme, Cotopaxi, Tungurahua.

\section{INTRODUCTION}

Volcanic ash can cause critical air pollution events and other significant impacts [1]. To protect public health and improve risk management, regions potentially affected should rely on information regarding the possible ash dispersion trajectories and ground sedimentation patterns (e.g. [2], [3]).

Ash emitted during explosive eruptions is dispersed by prevailing winds. Atmospheric Transport Models (ATMs) are pivotal for modeling volcanic ash dispersion and sedimentation (e.g. [4]-[6]). One of the components of any ATM is the meteorological driving model, which describes the state and evolution of the atmosphere in which the volcanic ash is introduced.

One meteorological parameter that influences in the dispersion and deposition of volcanic ash, is the Planetary Boundary Layer (PBL). The PBL is the bottom part of the atmosphere, which is influenced directly by the Earth's surface, and responds with a timescale of one hour or less [7]. The PBL depth can vary from a few tens of meters early in the day, to several kilometers by midday [8].

Turbulence is the dominant mechanism that transmits surface forcing throughout the PBL. Turbulence operates on scales that cannot be explicitly represented on grid scales and time steps used in most mesoscale models [9]. Hence, its effects are expressed in modeling trough PBL parameterization schemes. There are two major components by which turbulence is represented in numerical weather models: (1) the order of turbulence closure; (2) the use of 
a local or nonlocal mixing approach. Details of these two components are described in [10], [11]. Additionally there are different approaches in defining the PBL depth, as prescribed thresholds of the turbulent kinetic energy (TKE) or of the Richardson bulk number (Rib) [12]. Hence, PBL schemes can provide different PBL depths for the same region of modeling, affecting the dispersion of pollutants (e.g. [11]). They need to be assessed, especially in places where turbulent processes are particularly complex, such as the Andean region of Ecuador.

The Ecuadorian volcanic arc hosts about 85 quaternary volcanoes, 25 of which are erupting, active or potentially active. In the last 15 years, 5 volcanoes produced moderate to large explosive eruptions with significant ash plumes (Pichincha 1999-2001, Sangay permanent, Tungurahua 1999 to present, El Reventador 2002 to present, Cotopaxi 2015).

Tungurahua (Lon. $78.446^{\circ} \mathrm{W}$, Lat. $1.468^{\circ} \mathrm{S} ; 5023 \mathrm{~m}$ asl) is a large strato volcano located in the Real Cordillera of the Ecuadorian Andes (Fig. 1). Since the beginning of its current activity in October 1999, ash fallout has been the most frequent and widespread volcanic hazard [13], [14]. Based on seismic-acoustic signals from this volcano, some of the current explosive onsets have been characterized as vulcanian [15]. Based on field and numerical studies, Eruption Source Parameters (ESP) were proposed for forecasting ash dispersion and sedimentation from vulcanian eruptions at Tungurahua [6].

On 14 August 2015, Cotopaxi volcano (Lon. $78.436^{\circ} \mathrm{W}$, Lat. $0.677^{\circ} \mathrm{S} ; 5897 \mathrm{~m}$ asl, (Fig. 1)) awoke with its first eruption in 73 years, after approximately four months of precursory activity [16], [17]. Cotopaxi is an ice-capped stratovolcano located about $50 \mathrm{~km}$ south of Quito (capital of Ecuador (Fig. 1)). During 2015 the eruption activity, characterized by lowintensity ash venting, continued unevenly until the beginning of December [18].

This study assesses the performance in modeling the dispersion and sedimentation of volcanic ash in Ecuador, using different PBL schemes.

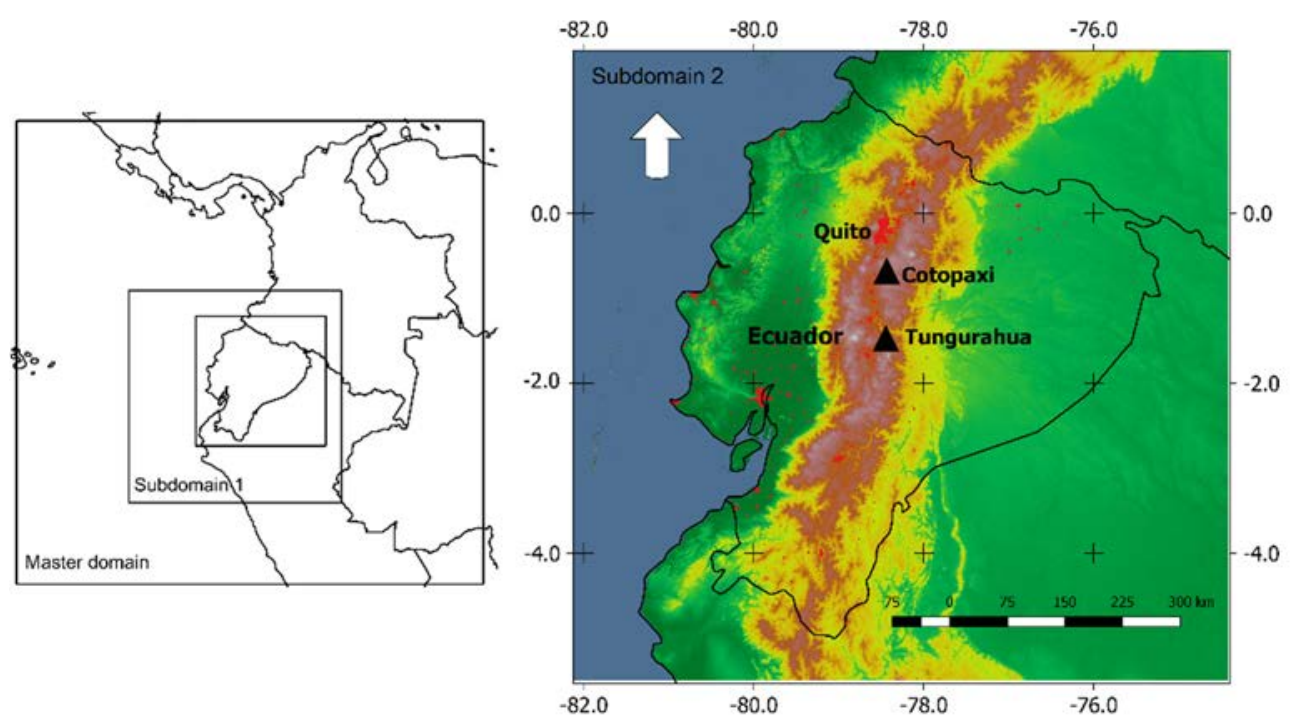

Figure 1: $(109 \times 109$ cells, $12 \times 12 \mathrm{~km})$, subdomain $2(199 \times 199$ cells, $4 \times 4 \mathrm{~km})$. Location of the Cotopaxi and Tungurahua volcanoes. 


\section{METHOD}

We modeled ash dispersion and sedimentation from eruptions at Tungurahua (16 Dec. 2012, 14 Jul. 2013 and 1 Feb. 2014) and Cotopaxi (14 Aug. 2015) volcanoes. For these dates we simulated the meteorology using the Weather Research and Forecasting (WRF3.7.1) model [19], though a master domain of $80 \times 80$ cells (each of $36 \times 36 \mathrm{~km}$ ) and two nested subdomains (Fig. 1), the second of which covers Ecuador with $199 \times 199$ cells $(4 \mathrm{~km}$ horizontal resolution) and 35 vertical levels (model top pressure at $50 \mathrm{hPa}, 22 \mathrm{~km}$ approximately). Initial and boundary conditions came from the GFS forecasts dataset [20]. Meteorological simulations were done considering 7 PBL schemes for WRF: (1) Yonsei University (YSU); (2) Mellor-Yamada-Janjic (MYJ); (3) Hong and Pan (GFS); (5) MellorYamada Nakanishi and Niino Level 2.5 (MYNN2.5); (6) Boulac PBL (BL); and (7) ShinHong (SH). Table 1 shows a summary of their features. After, the meteorological outputs, one of them being the PBL depth, were ingested into the FALL3DV7.1.4 [21] model to simulate ash dispersion and sedimentation from the 4 volcanic eruptions. Some of the options chosen for the ash dispersion simulations were: the surface layer option for vertical turbulence diffusivity, CMAQ for horizontal diffusion and Ganser for terminal velocity.

Modeled ash clouds were qualitative compared with ash clouds detected by the Washington Volcanic Ash Advisory Center (Washington VAAC) at different Flight Levels (FLs), the last based on satellite imagery, pilot reports and observatory information [22]. FLs are delivered in 100 feet units, measured above mean sea level when the pressure at sea level is $1013.2 \mathrm{mb}$ (e.g. FL300 $=30000$ feet, $\approx 9.1 \mathrm{~km}$ ).

Modeled ash fallout quantities were compared with records from ash meters located on stations around these volcanoes ( 4 for Tungurahua, 14 for Cotopaxi), which are operated by the Instituto Geofísico de la Escuela Politécnica Nacional [6], [18].

\section{RESULTS}

For all the eruptions and all the PBL schemes, the modeled ash clouds were fairly consistent with the detected. For example, Figs 2 and 3 show some detected ash clouds and the corresponding modeled results, when using the MYJ PBL scheme.

For the Tungurahua eruption on 16 Dec. 2012, at 12h15 Universal Time (UT), the detected ash cloud at FL400 was moving W, in the same direction of the modeled at $12 \mathrm{~h} 00 \mathrm{UT}$, although at FL300.

Table 1: WRF3.7.1 PBL schemes used for meteorological simulations over Ecuador.

\begin{tabular}{|c|l|c|c|c|c|}
\hline & Scheme & Nomenclature & $\begin{array}{c}\text { Order of } \\
\text { turbulence closure }\end{array}$ & $\begin{array}{c}\text { Mixing } \\
\text { approach }\end{array}$ & Reference \\
\hline 1 & Yonsei University & YSU & First & Nonlocal & {$[23]$} \\
\hline 2 & $\begin{array}{l}\text { Mellor-Yamada- } \\
\text { Janjic }\end{array}$ & MYJ & 1.5 & Local & {$[24]$} \\
\hline 3 & Hong and Pan & GFS & First & Nonlocal & {$[25]$} \\
\hline 4 & $\begin{array}{l}\text { Quasi-Normal Scale } \\
\text { Elimination }\end{array}$ & QNSE & 1.5 & Local & {$[26]$} \\
\hline 5 & $\begin{array}{l}\text { Mellor-Yamada } \\
\text { Nakanishi and Niino } \\
\text { Level 2.5 }\end{array}$ & MYNN2.5 & 1.5 & Local & {$[27]$} \\
\hline 6 & Boulac PBL & BL & 1.5 & Local & {$[28]$} \\
\hline 7 & Shin-Hong & SH & First & Nonlocal & {$[29]$} \\
\hline
\end{tabular}


For the eruption on 14 Jul. 2013, at 16h15 UT the detected clouds at FL320 and FL450 were moving NW-N-NE, while the modeled at $16 \mathrm{~h} 00$ UT were moving NW and N at FL300 and FL400 respectively. At this time, the modeled results show an ash cloud moving $\mathrm{W}$ at FL200, which was not detected by the Washington VAAC.

For the eruption on 1 Feb. 2014, at 23h15 UT, the detected clouds at FL230, FL400 and FL350, were moving SE, S and SW respectively, while the modeled clouds were moving S and SW.

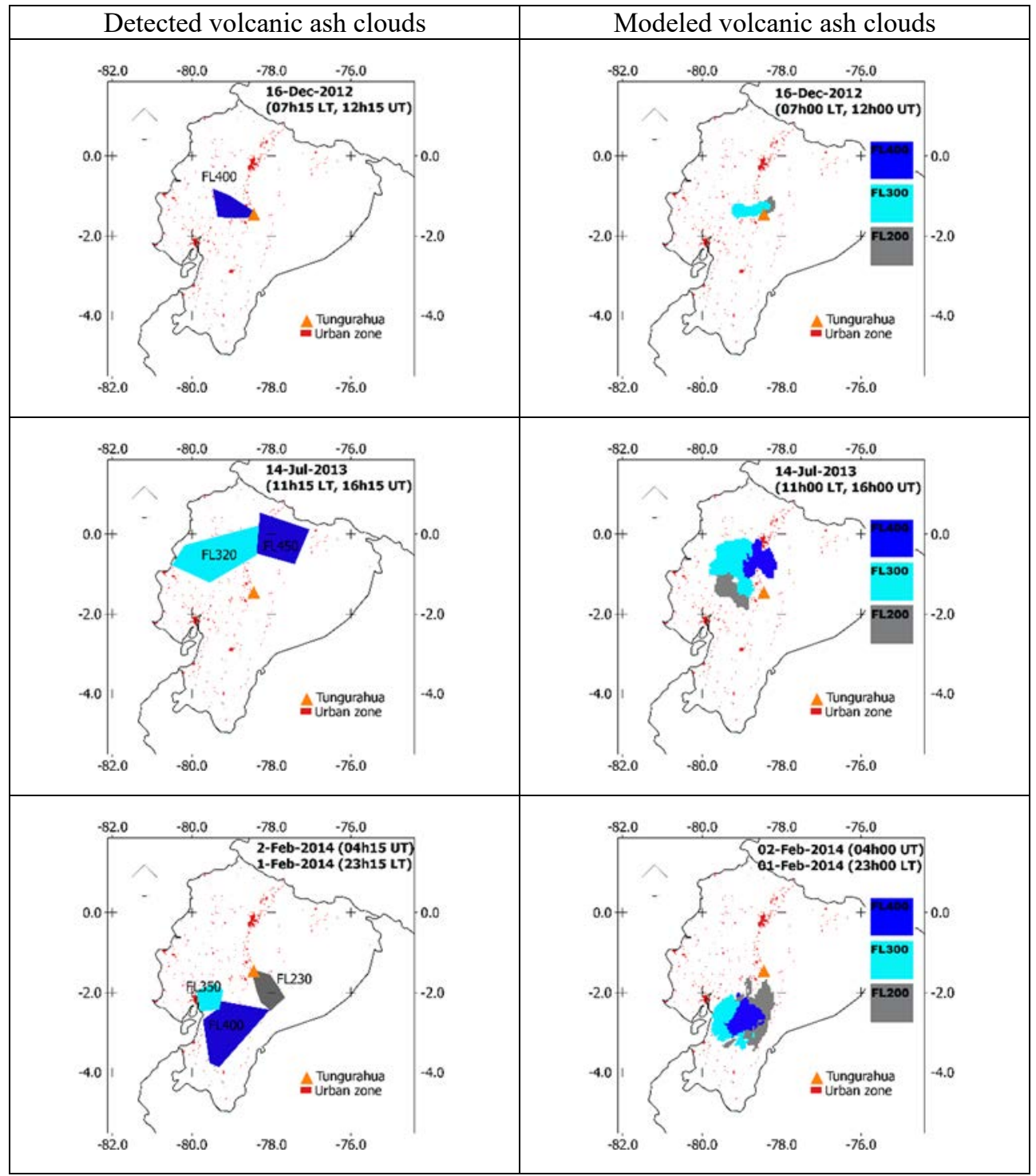

Figure 2: Left: Detected ash clouds [21] for modeled eruptions (16 Dec. 2012, 14 Jul. 2013, 1 Feb. 2014) at Tungurahua volcano. Right: Corresponding modeled ash clouds, using the MYJ PBL scheme. 


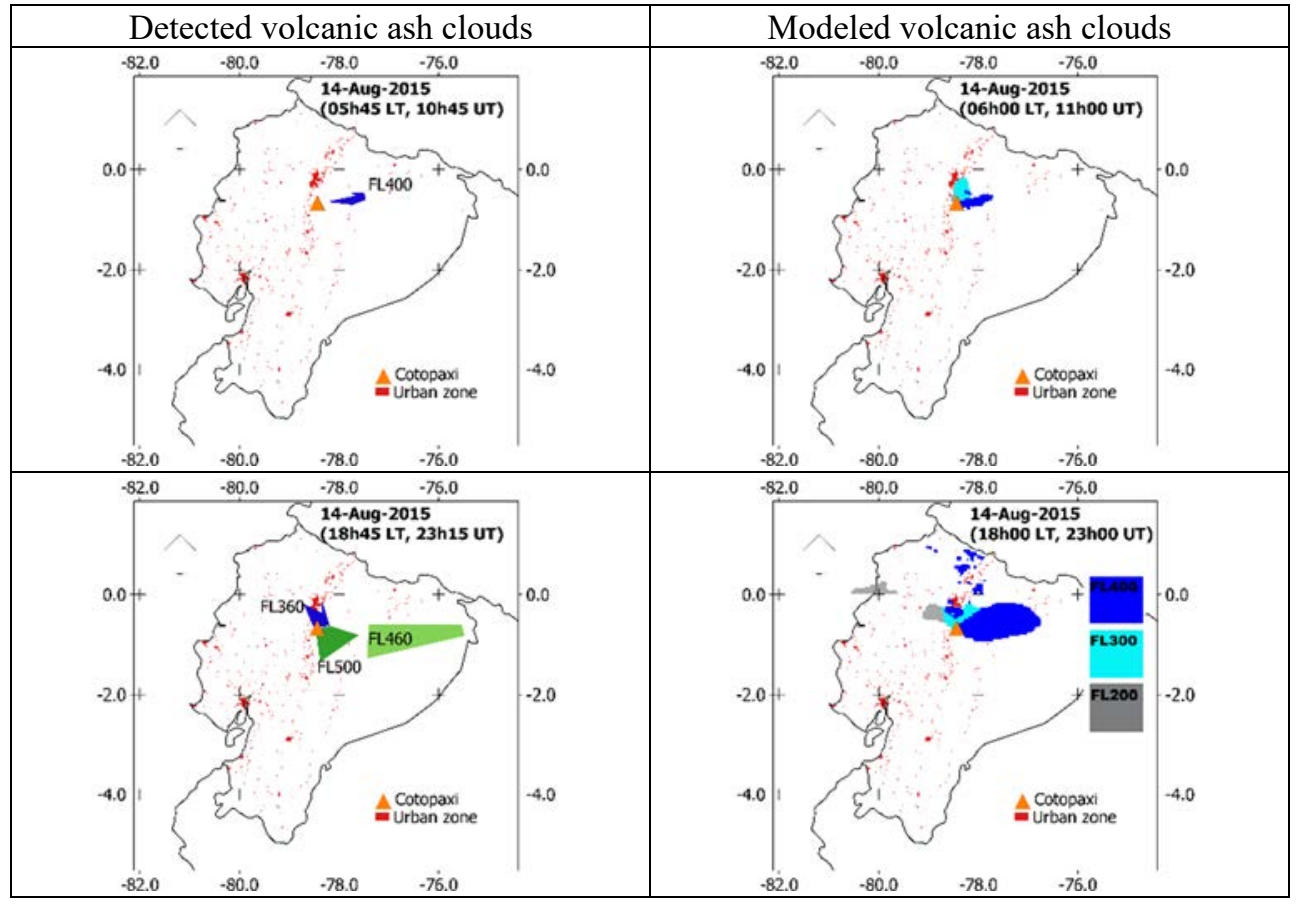

Figure 3: Left: Detected ash clouds [21] for the modeled eruption (14 Aug. 2015) at Cotopaxi volcano. Right: Corresponding modeled ash clouds using the MYJ PBL scheme.

For the Cotopaxi eruption on 14 Aug. 2015, at 23h15 UT, the detected ash clouds at FL400-FL500 and at FL360 were moving E and N respectively, the same directions of the corresponding modeled clouds at FL400 and at FL300. At this time, the modeled results show and ash cloud moving W at FL200, not detected by the Washington VAAC.

For all the eruptions at Tungurahua, the shape of the modeled ash clouds (at FL200, FL300 and FL400) using different PBL, were mostly similar. Nevertheless, for the eruption at Cotopaxi, although consistent, there were differences (Fig. 4).

The modeled ash fallout for the Tungurahua eruptions on 16 Dec. 2012, 14 Jul. 2013 and 1 Feb. 2014 took place mainly toward N, W and SW of the vent respectively (Fig. 5). The ash fallout for the Cotopaxi eruption on 14 Aug. 2015 took place mainly toward NW.

For all the eruptions, although modeling with different PBL schemes and the main direction of computed ash fallouts were the same (e.g. NW for the Cotopaxi eruption), there were differences in the final shape of the affected areas. The differences are mainly present in the ash fallout zones far from the vent. As example, Fig. 6 shows the modeled ash fallouts for the Cotopaxi eruption on 14 Aug. 2015.

The linear correlation coefficient $\left(\mathrm{R}^{2}\right)$ between measured and modeled ash fallout for the eruptions on 16 Dec. 2012, 14 Jul. 2013, 1 Feb. 2014 and 14 Aug. 2015, ranged from 0.98 to $1.0,0.62$ to $0.71,0.49$ to 0.60 and 0.34 to 0.55 , respectively (Fig. 7). The MYJ, GFS and QNSE schemes reached the best performances for the 4 eruptions, with average $\mathrm{R}^{2}$ values of $0.68,0.66$ and 0.66 , respectively. The MYJ PBL showed $\mathrm{R}^{2}$ values larger or equal to 0.5 , for all the eruptions (Figs 7 and 8). 


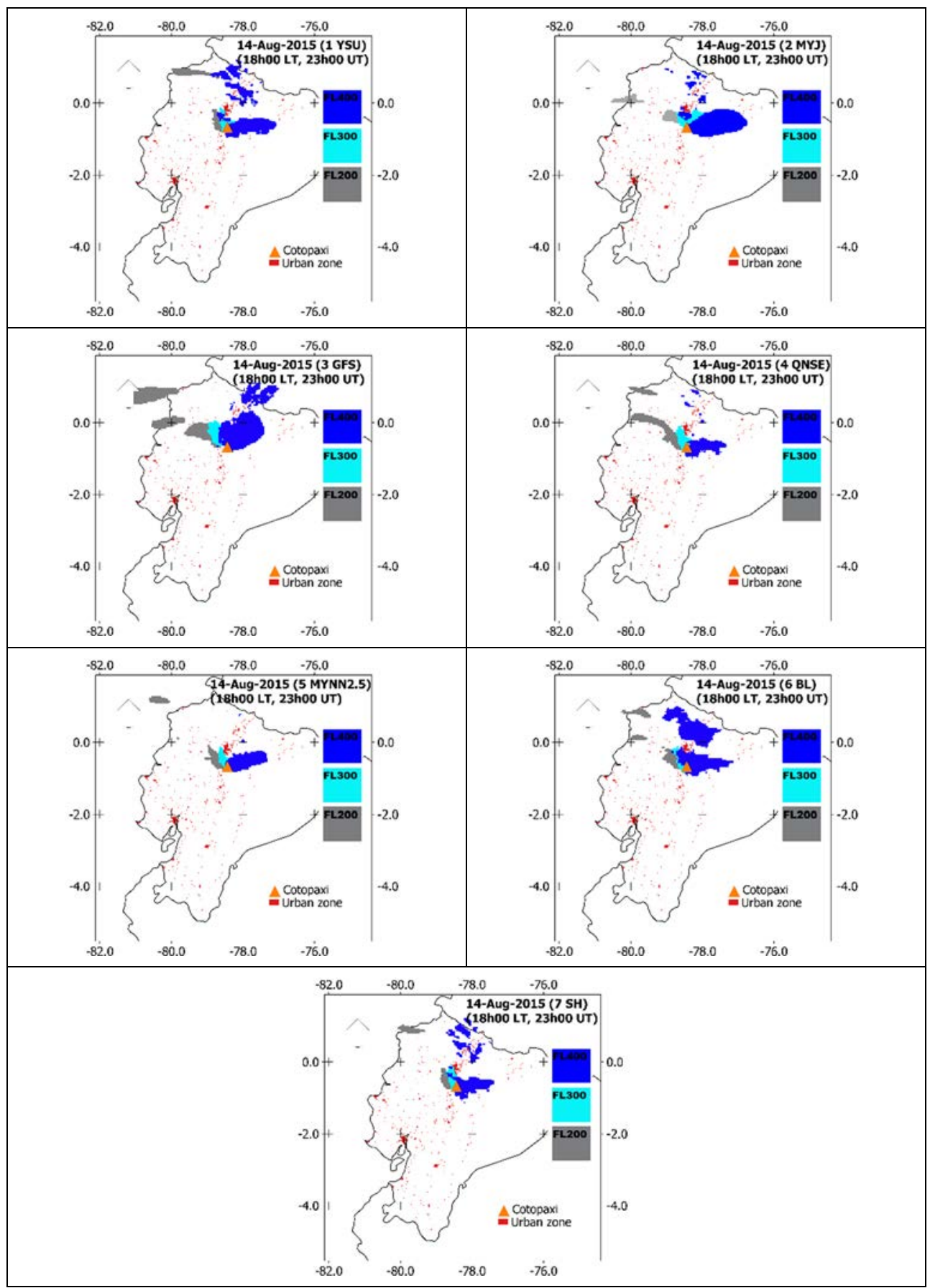

Figure 4: Cotopaxi volcano. Modeled ash clouds for the 14 Aug. 2015 eruption using different PBL schemes. 


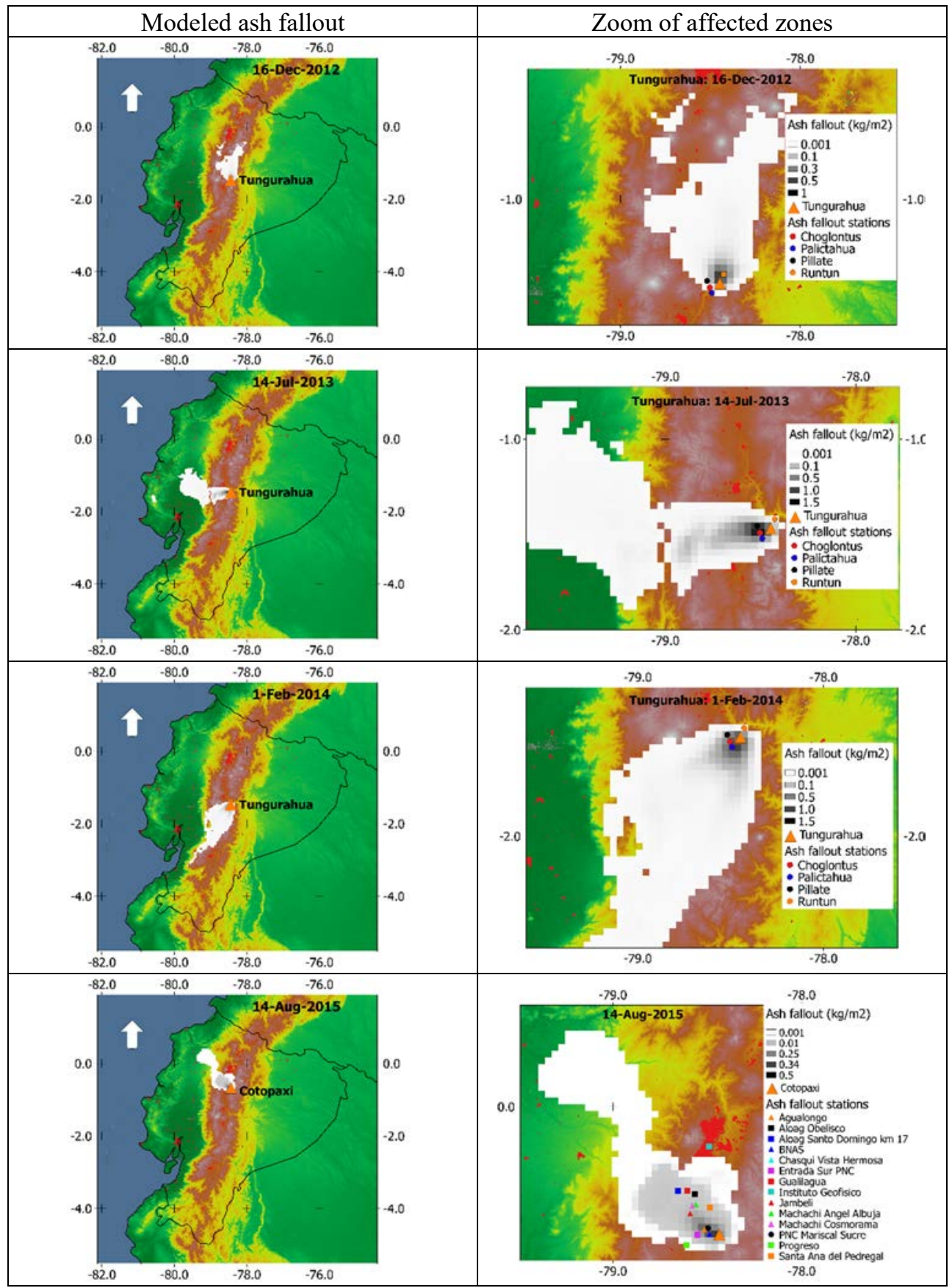

Figure 5: Left: Modeled ash fallout using the MYJ PBL scheme. Right: Zoom of affected zones with ash fallout larger than $0.001 \mathrm{~kg} / \mathrm{m}^{2}$ and location of fallout stations. 


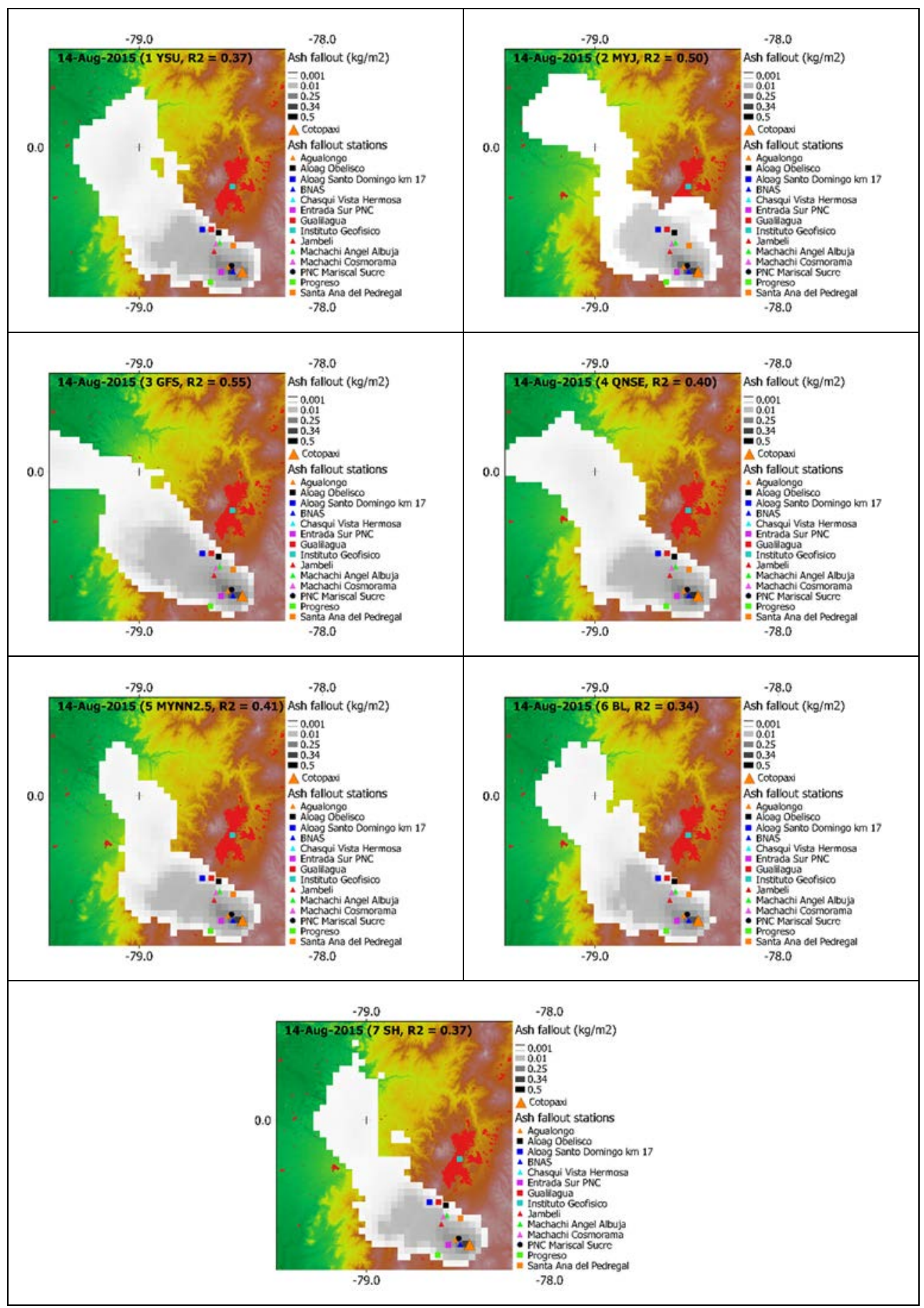

Figure 6: Cotopaxi volcano. Modeled ash fallout for the 14 Aug. 2015 eruption using different PBL schemes. 


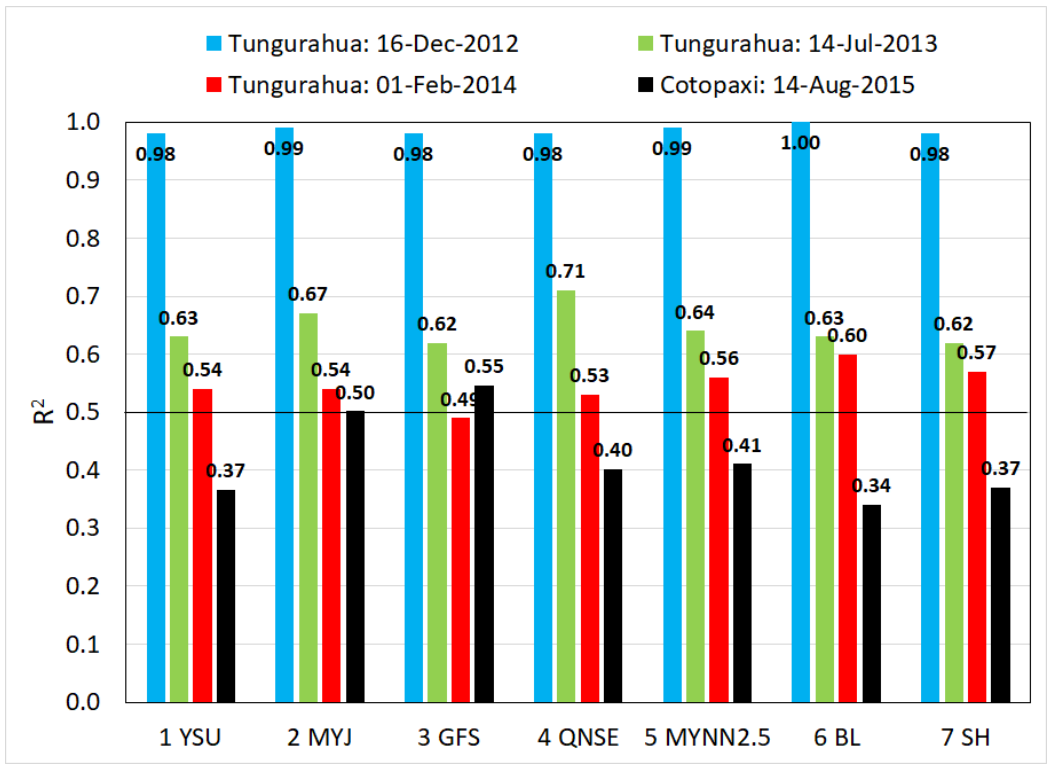

Figure 7: Linear correlation coefficient $\left(\mathrm{R}^{2}\right)$ between of measured and modeled ash fallout using different PBL schemes.

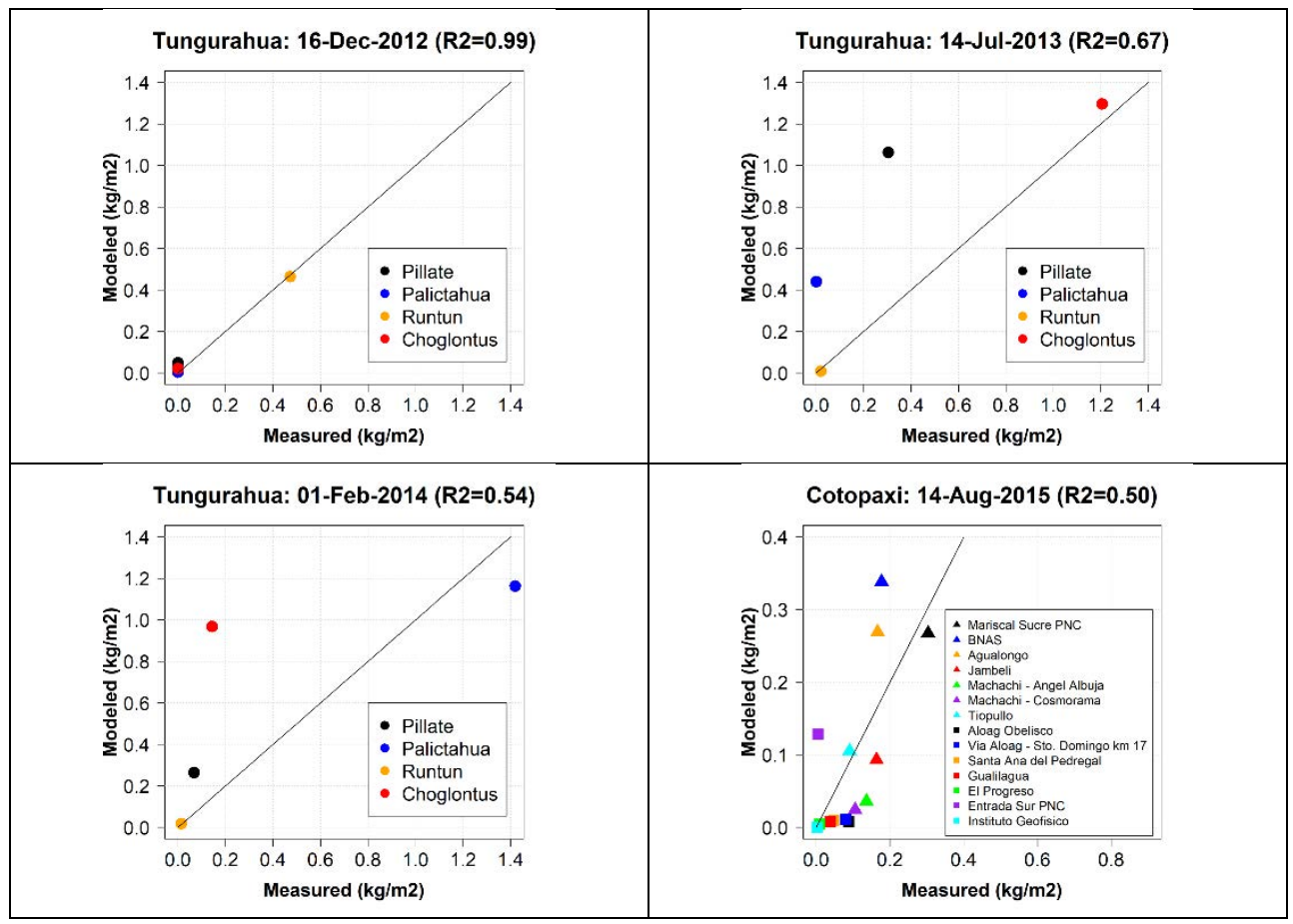

Figure 8: Linear correlation coefficient $\left(\mathrm{R}^{2}\right)$ between of measured and modeled ash fallout using the MYJ PBL scheme. 


\section{DISCUSSION AND CONCLUSIONS}

We used 7 PBL schemes for modeling the dispersion and sedimentation of 4 volcanic eruptions, which took place in Ecuador in the last 6 years.

In all cases, the modeled ash clouds were fairly consistent with the detected. For all the Tungurahua's eruptions the shape of modeled ash clouds, were mostly similar. Nevertheless, for the eruption at Cotopaxi, there were differences.

Although the PBL depth is involved in the vertical turbulence diffusion [30], which is expected to have negligible influence in comparison with horizontal diffusion processes, the results of this study indicate the PBL schemes can provide different performances in modeling ash fallout quantities. For all the eruptions, although using different PBL schemes, the main direction of modeled ash fallouts were the same. Nevertheless, there were differences in the final shape of the affected areas, mainly in the ash fallout zones far from the vent.

The MYJ PBL scheme (local, 1.5 order of closure) reached the best average performance $\left(\mathrm{R}^{2}=0.68\right)$ in modeling ash fallout quantities for all the eruptions. In other assessments, MYJ is among the PBL schemes that provided better performance when modeling the dispersion of air pollutants in the Andean region of Ecuador [11], [31]. These results suggest the MYJ PBL scheme could be a good choice both for volcanic ash dispersion and air quality modeling over this region.

When modeling vulcanian eruptions at Tungurahua, values of $\mathrm{R}^{2}$ (ash load measurements vs. computed fallout) ranged from 0.49 to 1.0 . The performance was lower, with $\mathrm{R}^{2}$ ranged from 0.34 to 0.55 , when modeling the Cotopaxi eruption.

Modeling volcanic ash dispersion is especially challenging in cases of very short duration of emissions and with complex dynamic, as the eruption on 14 Aug. 2015 of the Cotopaxi volcano (6 explosions unevenly timed with heights ranged from 8.0 to $9.3 \mathrm{~km}$ above the vent, lasting about $30 \mathrm{~s}$ each one). This complexity could explain in part the lower performances when modeling this eruption, in comparison with less complex and longer vulcanian eruptions at Tungurahua (prescribed ESP, which consider 2 explosions with heights above the vent of $8.80 \mathrm{~km}$ and $4.85 \mathrm{~km}$, lasting 3 min and 22 min respectively).

Convective movements of the atmosphere promote the formation of clouds, which could not allow satellite tracking of ash plumes. Such a situation is highly probable in the Andean region of Ecuador, where convective wet air masses, as those coming from the coast and the Amazon regions or by the presence of the Intertropical Convergence Zone, typically promote the formation of clouds. In Ecuador and other regions with similar features, modeling could be particularly useful for a more complete description of volcanic ash dispersion and sedimentation processes. In cases as the eruptions on 14 Jul. 2013 and on 14 Aug. 2015, satellite sensors could detect volcanic ash only over the cloud layers, although the dispersion at bottom levels can happen in different way, producing the ash fallout toward different directions than observed by remote sensing.

In cases of eruptions with low column heights and during cloudy conditions, satellites could even not detect ash clouds. In these cases, the modeling approach can provide unique information about the regions potentially affected by ash fallout.

In the future, to improve the performance when modeling ash dispersion and sedimentation in Ecuador, it is necessary to explore the influence of other parameters as the influence of the terminal velocity model or ash aggregations processes. 


\section{ACKNOWLEDGEMENTS}

This research is part of the project "Calidad del Aire en el Ecuador" funded with the USFQ Poli-Grants 2017-2018. Simulations were done at the High Performance Computing System at the USFQ.

\section{REFERENCES}

[1] Ayris, P.M. \& Delmelle, P., The immediate environmental effects of tephra emission. Bulletin of Volcanology, 74, pp. 1905-1936, 2012. DOI: 10.1007/s00445-012-0654-5.

[2] Horwell, C.J. \& Baxter P.J., The respiratory health hazards of volcanic ash: A review for volcanic risk mitigation. Bulletin of Volcanology, 69(1), pp. 1-24, 2006.

[3] Wilson, T.M. \& Stewart, C., Volcanic ash. Encyclopedia of Natural Hazards, ed. P. Bobrowsky, Springer, p. 1000, 2012.

[4] Folch, A., Jorba, O. \& Viramonte, J., Volcanic ash forecast - application to the May 2008 Chaitén eruption. Natural Hazards and Earth System Sciences, 8, pp. 927-940, 2008. DOI: 10.5194/nhess-8-927-2008.

[5] Wilkins, K. et al., Volcanic ash cloud forecasting: combining satellite observations and dispersion modelling. Geophysical Research Abstracts, 16, p. 1615, 2014.

[6] Parra, R., Bernard, B., Narváez, D., Le Pennec, J.-L., Hasselle, N. \& Folch, A., Eruption source parameters for forecasting ash dispersion and deposition from vulcanian eruptions at Tungurahua volcano: Insights from field data from the July 2013 eruption. Journal of Volcanology and Geothermal Research, 309, pp. 1-13, 2016. DOI: 10.1016/j.jvolgeores.2015.11.001.

[7] Stull, R., An Introduction to Boundary Layer Meteorology. Kluwer Academic: Dordrecht, The Netherlands, 666 pp., 1988.

[8] Stensrud, D., Parameterization Schemes, Keys to Understanding Numerical Weather Prediction Models. Cambridge University Press: New York, 459 pp., 2007.

[9] Stull, R., Meteorology for Scientist and Engineers. 2nd ed., Brooks/Cole Thomson Learning: USA, 502 pp., 2000.

[10] Cohen, A., Cavallo, S., Coniglio, M. \& Brooks, H., A review of planetary boundary layer parameterization schemes and their sensitivity in simulating southeastern U.S. cold season weather environments. Journal Weather and Forecasting, American Meteorological Society, 30, pp. 591-612, 2015.

[11] Parra, R., Performance studies of planetary boundary layer schemes in WRF-Chem for the Andean region of southern Ecuador. Atmospheric Pollution Research, 9(3), pp. 411-428, 2017. https://doi.org/10.1016/j.apr.2017.11.011.

[12] Banks, R. et al., Sensitivity of boundary-layer variables to PBL schemes in the WRF model based on surface meteorological observations, lidar, and radiosondes during the HygrA-CD campaign. Atmospheric Research, 176-177, pp. 185-201, 2016.

[13] Le Pennec, J.L., Ruiz, G.A., Ramón, P., Palacios, E., Mothes, P. \& Yepes, H., Impact of tephra falls on the Andean communities: the influences of eruption size and weather conditions during the 1999-2001 activity of Tungurahua volcano, Ecuador. Journal of Volcanology and Geothermal Research, 217-218, pp. 91-103, 2012. http://dx.doi.org/ 10.1016/j.jvolgeores. 2011.06.011.

[14] Bernard, B., Bustillos, J., Wade, B. \& Hidalgo, S., Influence of the wind direction variability on the quantification of tephra fallouts: December 2012 and March 2013 Tungurahua eruptions. Avances en Ciencias e Ingenierías, 5(1), pp. A14-A21, 2013.

[15] Kim, K., Lees, J.M. \& Ruiz, M.C., Source mechanism of vulcanian eruption at Tungurahua volcano, Ecuador, derived from seismic moment tensor inversions. 
Journal of Geophysical Research, Solid Earth, 119, pp. 1145-1164, 2014. http://dx.doi.org/10.1002/2013JB010590.

[16] Hidalgo, S. et al., IGEPN, Cotopaxi volcano's unrest and eruptive activity in 2015: Mild awakening after 73 years of quiescence. In: Abstract Volume of the 2016 EGU General Assembly, p. EGU2016-5043-1, 2016.

[17] Gaunt, H.E. et al., Juvenile magma recognition and eruptive dynamics inferred from the analysis of ash time series: The 2015 reawakening of Cotopaxi volcano. Journal of Volcanology and Geothermal Research, 328, pp. 134-146, 2016.

[18] Bernard, B. et al., Relationship between volcanic ash fallouts and seismic tremor: quantitative assessment of the 2015 eruptive period at Cotopaxi volcano, Ecuador. Bulletin of Volcanology, 78, p. 80. DOI: 10.1007/s00445-016-1077-5, 2016.

[19] Weather Research and Forecasting Model, http://wrf-model.org. Accessed on: 25 Sep. 2017.

[20] Global Forecast System (GFS), www.ncdc.noaa.gov/data-access/model-data/modeldatasets/global-forcast-system-gfs. Accessed on: 25 Sep. 2017.

[21] Folch, A., Costa, A. \& Macedonio, G., FALL3D: A computational model for transport and deposition of volcanic ash. Computers \& Geosciences, 35(6), pp. 1334-1342, 2009.

[22] Washington VAAC, www.ssd.noaa/VAAC/washington html. Accessed on: 27 Jan. 2018.

[23] Hong, S., Noh, S. \& Dudhia, J., A new vertical diffusion package with an explicit treatment of entrainment processes. Monthly Weather Review, 134, pp. 2318-2341, 2006.

[24] Janjic, Z., The step-mountain eta coordinate model: Further developments of the convection, viscous sublayer, and turbulence closure schemes. Monthly Weather Review, 122, pp. 927-945, 1994.

[25] Hong, S. \& Pan, H., Nonlocal boundary layer vertical diffusion in a medium-range forecast model. Monthly Weather Review, 124, pp. 2322-2339, 1996.

[26] Sukoriansky, S., Galperin, B. \& Perov, V., Application of a new spectral theory of stably stratified turbulence to the atmospheric boundary layer over sea ice. BoundaryLayer Meteorology, 177, pp. 231-257, 2005.

[27] Nakanishi, M. \& Niino, H., An improved Mellor-Yamada level-3 model: Its numerical stability and application to a regional prediction of advection fog. Boundary-Layer Meteorology, 119, pp. 397-407, 2006.

[28] Bougeault, P. \& Lacarrère, P., Parameterization of orography-induced turbulence in a mesobeta-scale model. Monthly Weather Review, 117, pp. 1872-1890, 1989.

[29] Shin, H. \& Hong, S., Representation of the subgrid-scale turbulent transport in convective boundary layers at gray-zone resolutions. Monthly Weather Review, 143, pp. 250-271, 2015. DOI: 10.1175/MWR-D-14-00116.1.

[30] Folch, A., Costa, A. \& Macedonio, G., FALL3D-7.2 User's manual, June, 2017.

[31] Parra, R., Assessment of planetary boundary layer schemes of the WRF-Chem model in the simulation of carbon monoxide dispersion in the urban area of Quito, Ecuador. WIT Transaction on Ecology and the Environment, vol. 211, WIT Press: Southampton and Boston, 2017. DOI: 10.2495/AIR170041. 